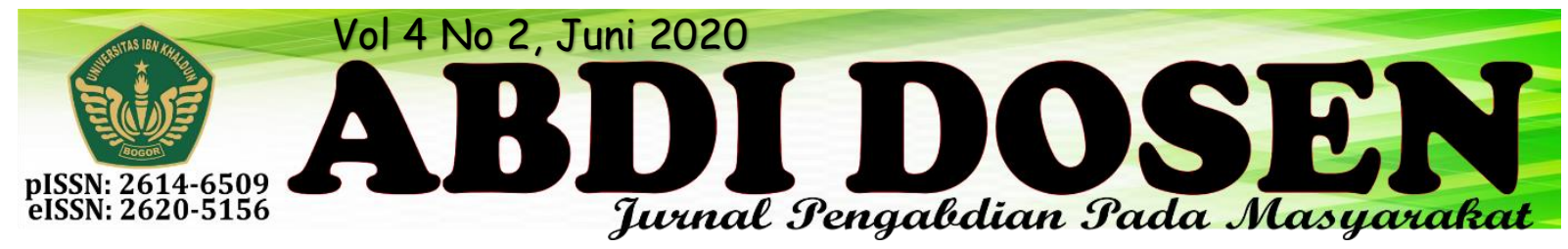

\title{
MEMPERKENALKAN CARA PENGAPLIKASIAN KOMPUTER TERHADAP ANAK SEKOLAH DASAR (CIAMPEA UDIK, CARINGIN JANGKUNG)
}

\author{
Dewi Suryani Djamdjuri ${ }^{1}$, Galuh Candra Kirana Putri Prasetya ${ }^{2}$ \\ dewi.suriyani@uika-bogor.ac.id
}

Fakultas Keguruan dan Ilmu Pendidikan Universitas Ibn Khaldun ${ }^{1}$, Mahasiswa KKN Kelompok 12 Tahun $2018^{2}$

\begin{abstract}
ABSTRAK
Program Kuliah Kerja Nyata (KKN) merupakan bentuk kegiatan pengabdian kepada masyarakat oleh mahasiswa dengan pendekatan lintas keilmuan dan sektoral pada waktu dan daerah tertentu (Mada, 2014). Dalam pelaksanaannya, kegiatan KKN saya berlangsung selama 1 bulan lamanya, dan ditempatkan setingkat Desa. Seperti yang telah di tetapkan, bahwa kegiatan KKN ini menjadi kewajiban yang ditetapkan Direktorat Jenderal Pendidikan Tinggi di Indonesia, yang menyatakan setiap Perguruan Tinggi untuk dapat melaksanakan KKN sebagai kegiatan intrakulikuler yang memadukan aspek Tri Dharma Perguruan Tinggi, yakni Pendidikan, Penelitian, dan pengabdian kepada masyarakat. (Yunior, 2014) Program KKN Tematik merupakan metode KKN yang diterapkan oleh universitas Ibn Khaldun Bogor. Dalam pelaksanaannya KKN Tematik adalah kegiatan KKN yang berorientasi pada bidang tertentu sesuai permasalahan yang dirasa oleh masyarakat serta arah kebijakan pemerintahan setempat. Oleh karena itu, saya melakukan perkenalan komputer pada kegiatan yang berbasis problem solving pada setiap program kerja yang dilaksanakan pada target masyarakat setempat. Dari hasil observasi yang dilakukan di saat pra KKN dan secara kondisional saat KKN berlangsung, saya pun melihat berbagai factor permasalahan diantaranya, faktor pendidikan dan Keagamaan. Bidang Kerja pendidikan dan keagamaan berdasarkan pembagian bidang kerja inilah saya berharap kedatangan saya dapat memberikan nilai manfaat sesuai dengan tujuan saya, yakni memperkenalkan dasar-dasar komputer dan pemahaman akan pentingnya teknologi di masa sekarang.
\end{abstract}

\section{Kata Kunci : KKN, Pengaplikasian Komputer, Pengabdian}

\section{PENDAHULUAN}

\section{Latar Belakang}

Sebagai mahasiswa yang merupakan mahluk terdidik dan di dayagunakan sebagai manusia yang dapat membawa alur perubahan bagi lingkungan masyarakat, atau yang biasa disebut sebagai agent of Change. Mengemban tugas yang berkaitan dengan kemasyarakatan. Mahasiswa yang menjadi subjek dari Perguruan Tinggi, tentunya memiliki amanah yang dimiliki oleh Kampus, yakni merealisasi Tri Dharma Perguruan Tinggi yang aspeknya terdiri dari Pendidikan, Pengabdian, dan Penelitian.

Dalam pelaksanaannya itulah Perguruan Tinggi menyediakan waktu bagi mahasiswanya untuk dapat melakukan perkuliahan non kelas, yang merupakan 
penilaian dari SKS. Perkuliahan non kelas ini biasa dikenal juga sebagai Kuliah Kerja Nyata (KKN). Dengan tujuan adanya KKN ini agar mahasiswa dapat melatih kompetensinya di lingkungan masyarakat, serta melatih empati mahasiswa dalam kegiatan yang bermanfaat bagi masyarakat, menjadikan mahasiswa yang dapat hidup bermasyarakat dan menjadikan mahasiswa sebagai inspirator bagi remaja maupun masyarakat sekitar.oleh sebab itu, melalui Kuliah Kerja Nyata ini, mahasiswa membuat program- program yang kiranya dapat membantu da memberikan manfaat bagi masyarakat serta memediasi masyarakat dalam memenuhi kebutuhannya pada pihak desa setempat.

\section{Kondisi Wilayah}

KKN Tematik UIKA Kelompok 12, berlokasi di Desa Ciampea Udik, Kecamatan Ciampea Kabupaten Bogor. desa ciampea Udik berada di jalan Raya Cikampak- Segog, Kampung Laladon RW 09. Desa tersebut memiliki luas wilayah 243. 150 Ha. Memiliki ketinggian $100 \mathrm{~m}$ diatas permukaan laut dan terbagi 4 Dusun, 9 RW dan 27 RT. Adapun batas wilayah Desa Ciampea Udik yakni ;

1. Sebelah Utara berbatasa dengan Desa Cibuntu kecamatan Ciampea

2. Sebelah Selatan berbatasan dengan desa Cibening kecamatan Pamijahan

3. Sebelah Timur berbatasa dengan Desa Cibitung kecamatan Tenjolaya

4. Sebelah Barat berbatasan dengan Desa Ciaruteun Kecamatan Cibungbulang

Adapun kondisi masyarakat yang ada di wilayah tersebut, rata- rata masyarakat disana merupakan masyarakat asli kampung atau masyarakat yang turuntemurun dari keluarga yang sudah menempati wilayah setempat. Rata- rata dari informasi yang saya dapatkan, masyarakat di kampung Caringin Jangkung II yang merupakan wilayah RW 09, masih saling terikat tali persaudaraan darah antara satu dengan yang lainnya. Mereka ketika sudah berkeluarga akan tetap bertempat tinggal di kampungnya, sehingga hal itulah yang membuat mereka tidak hidup berjauhan antara satu saudara dengan saudara yang lain. Dan berdasar pengetahuan saya atas kondisi mata pencaharian mereka dalam mendapatkan uang yakni hampir rata- rata para bapakbapak dan ibu- ibu disana sebagai penggarap ladang pertanian dan sebagian menjadi petani. Mereka sebagian ada yang menggeluti pertanian umbi- umbian, rempah- rempah, maupun petani dalam sektor budidaya perikanan. Adapun dalam hal pendidikan, rata- rata para orang tua yang masih berusia muda merupakan lulusan dari tamatan akhir di tingkat sekolah menengah pertama maupun sekolah (SMP) menengah Atas (SMA). Sedangkan anak- anak mudanya sebagian besar lulusan dari tingkat SMA. Hasil pengamatan kami secara kondisi sosial, di kampung tersebut warganya berada pada tingkat sosial menengah kebawah. Para pemuda disana sebagian besar merupakan pemuda yang kurang berproduktif karena belum adanya pekerjaan yang dimiliki. hal itu diperparah dengan kondisi pemuda yang dirasa kekurangan nilai- nilai pemahaman keagamaan. Namun, hal yang masih disyukuri yakni bapak- bapak, ibuibu dan anak- anak setempat masih memilki wadah pengajian meskipun jumlah dari mereka yang mengikuti pengajian masih belum terdominasi mereka yang aktif mengaji. 


\section{METODE DAN REALISASI}

Metode Pengabdian

Adapun langkah awal dari kegiatan saya ini yakni melakukan survey dan observasi terlebih awal sebelum adanya ketentuan waktu yang resmi untuk melakukan perizinan tinggal dan pelaksanaan KKN. Setelah adanya gambaran dari tempat $\mathrm{KKN}$, tahap selanjutnya yakni mengikuti kegiatan penyuluhan TOT yang diperuntukkan bagi setiap Dosen Pembimbing Lapangan dan Ketua kelompok. Maka dapat saya paparkan, metode pelaksanaan saya yakni;

a. Metode survey dan obeservasi

Pengamatan adalah pengumpulan data yang dilakukan dengan cara mengamati dan mencatat secara sistematik gejala- gejala maupun situasi desa Ciampea Udik. Pada metode ini, penulis langsung mengamati secara langsung di saat pra pelaksanaan KKN, pelaksanaan $\mathrm{KKN}$, serta fenomena atau dampakdampak yang terjadi setelah adanya program- program yang dilaksanakan. Data yang diperlukan dalam metode pengamatan ini yakni mengamati secara langsung di lokasi, pelaksaan proses $\mathrm{KKN}$, dan kegiatan-kegiatan masyarakat desa Ciampea Udik, khususnya warga kampung Caringin Jangkung II RW.09 yang merupakan wilayah kampung konsentrasi KKN saya, termasuk kegiatan para pemuda dan pemudi dan anak- anak kecil.

b. Metode Interview

Metode ini juga biasa disebut sebagai metode wawancara yakni suatu metode pengumpulan data yang dilakukan melalui Tanya jawab secara langsung dengan menggunakan sumber- sumber data.
Dalam pengajuan wawancara ini, merupakan alat pengajuan pertanyaan yang menggunakan lisan dan dijawab dengan lisan juga. Dalam metode ini hal yang menjadi cirinya yakni dengan bertatap muka langsung. Dalam wawancara yang dilakukan, para peneliti bertemu dan bertanya kepada perangkat desa, tokoh kampung dan pemuda setempat, RT/ RW, ataupun warga pada umumnya.

\section{Realisasi Program}

Selain dari program utama dari pengaplikasian pembelajaran komputer, ada beberapa program yang kerjakan juga. Berikut program-program yang kami realisasikan untuk pengabdian kepada masyarakat:

a. Program Bantuan Pengajar di Madrasah Ibtidaiyah Al Arsaniyah

b. Program Pengajian anak- anak di Majelis Talim RT 01

c. Program Pelatihan Microsoft

d. Program Penyuluhan Pendidikan Keluarga Islami

e. Program kerja pengadaan lomba untuk anak- anak dan ibu- ibu RT 01 dan RT 02

f. Program renovasi cat tembok majelis ta'lim RT 01/RW 09

g. Program Kerja Partisipasi Kegiatan Penyuluhan Puskesmas Ciampea Udik Di Rt 01/Rw 09

h. Program jalan sehat bersama anak- anak pengajian RT 01 dan RT 02

i. Program perbantuan desa untuk program jalan sehat bersama warga

j. Program bebersih dengan anak- anak pengajian di lingkungam mesjid majelis ta'lim RT 01, dan posko 


\section{KESIMPULAN DAN DAMPAK BAGI MASYARAKAT}

1. Dalam program kerja yang saya lakukan di Ciampea Udik kp.Caringin jangkung membuat efek positif bagi masyarakat setempat, Dalam program pelatihan Microsoft, kesimpulan program ini bahwa program ini diharapkan dapat mengenalkan perangkat computer pada anak- anak, serta mengenalkan cara operasikan computer/ laptop. Dalam pelaksanaannya anak- anak diminta untuk menggunakan aplikasi Microsoft Word. Dampak yang terlihat dari pelaksanaan program ini yakni anakanak antusias dalam proses belajar dan mengetahui dan menggunakan aplikasi tersebut. Serta anak- anak bisa memanfaatkan fasilitas pengajaran itu untuk tugas sekolahnya.

Saran yang diberikan untuk desa : pihak desa harus bisa memaksimalkan fasilitas pemanfaatan sekolah yang ada di teritorialnya. Khususnya dalam pengadaan fasilitas computer di sekolahan. Agar pengetahuan tentang teknologi dapat dirasakan oleh anakanak sekolah setempat.

Terutama untuk anak sekolah dasar yang sangat perlu bimbingan dalam bidang teknologi. Yakni sangat dasar yaitu memperkenalkan komputer dalam microsoft office. Dalam perkenalkan komputer anak-anak sangat antusias dan sangat bersemangat untuk lebih tau lebih dalam, karena hampir semua anak-anak di daerah carigin jangkung yang bisa di bilang sangat awam dalam pengetahuan komputer. Setelah perkenaan dan pembeajaran komputer anak-anak sudah sedikit mengerti dan bisa menggunakan komputer/laptop dalam pengaplikasikan microsoft office. Kegiatan ini di lakukan di sore hari jam 16.00-17.30 wib. Disetiap 1x pertemuan ada pembagian materi agar anak-anak lebih mudah faham dan cepat tangkap untuk pemberian materi disetiap pertemuan nya. Dari kegiatan ini dapat pengetahuan baru karna sangat tertinggal dalam pengetahuan komputer salah satunya untuk menyalakan komputer/laptop saja tidak mengerti, tapi setelah ada pembelajaran atau bisa disebut pelatihan microsoft office dapat pengetahuan baru dan bisa lebih mengerti soal komputer atau lebih dalam tentang microsoft office.

2. Bagi masyarakat dalam pengajaran TPA, anak - anak menjadi lebih antusias dalam mengaji dan memperdalam ilmu agama, mereka sangat bersemangat dikerenakan ada orang baru yang mengajar mereka. TPA yang tadinya sepi menjadi ramai ketika mahasiswa dan mahasiswi datang ke kampung Caringin Jangkung 2, begitu juga dampak yang terjadi dalam pengajaran Di Madrasah Ibtidaiyah Al Arsaniyah berdampak positif, anak anak menjadi lebih antusias dalam belajar karena mendapat metode yang berbeda dari Guru - guru yang ada di sekolahan tersebut, dengan pembelajaran yang tidak monoton yang membuat murid - murid nyaman dengan pembelajaran tersebut, membuat murid lebih bisa memahami pembelajaran dan tidak jenuh. Itu yang membuat anak - anak menjadi betah diajar dengan mahasiswa dan mahasiswi. Dan jika dampak pada masyarakat dalam program partisipasi pengajian ibu - ibu, masyarakat merasa lebih senang dengan adanya mahasiswi yang ikut berpartisipasi dalam pengajian, apalagi sebelum melaksanakan pengajian selalu 
melantunkan sholawatan yang dilantunkan oleh tokoh agama beserta mahasiswi. Ini membuat ibu - ibu lebih bersemangat dalam mengikuti pengajian yang rutin dilaksanakan tiap hari senin jam 13.00 dan mereka menganggap mahasiswi berperan aktif dalam pengajian di kampung Caringin Jangkung 2 tersebut. Saran yang ingin diberikan kepada pihak desa, sejauh ini pihak Desa sudah melayani masyarakatnya dengan cukup baik, dengan fasilitas - fasilitas yang memadai namun akan lebih baik jika sarana dan prasarana lebih di tingkatkan lagi terkhusus dalam bidang pendidikan yang notabennya yayasan, alangkah lebih baik kondisi fisik bangunan dan kebersihan harus ditingkatkan agar masyarakat lebih nyaman dalam beraktifitas sehari - harinya. Dan tenaga Guru di Kampung Caringin Jangkung 2 harus di perhatikan karena tidak memadai, ini membuat siswa yang belajar tidak mendapatkan ilmu yang maksimal begitupun dengan TPA. Dengan memperbaiki hal tersebut maka Kampung Caringin Jangkung 2 akan lebih maju lagi dalam segala bidang terkhusus bidang Pendidikan.

3. Kesimpulan dari pelaksanaan bimbingan belaja bahasa Inggris, yakni program ini merupakan program yang menargetkan anak- anak SD/ MI. program yang dilakukan bagi anakanak sekitaran posko mahasiswa ini, memberikan materi pembelajaran yang berkaitan bahasa inggris tentunya dan juga melalui lagu- lagu bahasa inggris. Diharapkan dengan adanya metode melalui lagu- lagu, anak- anak dapat terlatih berbicara bahasa inggris atau speaking, begitu juga dengan reading, listening, dan writing. Maka dari itu kami mengasah kemampuan bahasa inggris anak- anak, serta memberikan daya tarik pada anak- anak pada kemauan mempelajari bahasa inggris. Dampak yang terjadi, anak- anak semakin semangat belajar bahasa inggris. Dan anak- anak meminta bantuan mengerjakan PR nya ke para mahasiswa yang menjadi pembimbing belajar.

Saran yang diberikan untuk desa : desa dapat memberikan akses atau fasilitas tempat bimbingan belajar di setiap desa, dengan memanfaatkan sumber daya pengajar di sekolah yang ada di Dusun atau Desa setempat. Desa juga diharapkan memberikan penyuluhan pada remaja setempat agar mau semangat mempelajari bahasa asing.

4. Kesimpulan dari program movie club discussion yakni kegiatan ini diadakan untuk menghibur dan mengajak bermain sekaligus memasukkan unsureunsure pembelajaran bahasa inggris. Salah satu nilai utama dalam program ini yakni program ini disertai dengan ilmu- ilmu atau materi islami yang melalui bahasa inggris. Film yang disuguhi berdurasi 10 menit. Setelah usai, anak- anak diajak berdiskusi, dengan begitu anak- anak dapat menambah kosa kata atau vocabulary baru. Dampak yang terlihat, anak- anak senang dan antusias dalam mengucapkan komunikasi dalam bahasa inggris. Mereka juga mendapatkan pengetahuan akan ilmu- ilmu keislaman.

Saran yang diberikan kepada Desa ; pihak desa harus memberikan himbauan pada para pengajar khususnya pengajar bahasa inggris untuk menerapkan metode pembelajaran yang kreatif seperti halnya movie club discussion. 
Desa juga harus melengkapi sarana multimedia bagi sekolah- sekolah yang ada di wilayahnya.

5. Kesimpulan program partisipasi pengajian ibu- ibu dan bapak- bapak, yakni keikutsertaan kami dalam kegiatan ini, mmerupkan niatan untuk beribadah dan menjadikan factor mediasi kami untuk dapat dekat dengan masyarakat sekitar. Dampak yang terlihat yakni, bapak- bapak dan ibuibu dapat berhubungan dan berkomunikasi lebih dekat dengan kami. Kami pun lebih mudah dalam menggerakkan masyarakat dalam pelaksanaan program- program lainnya.

Saran untuk desa : desa agar tetap dapat menjaga dan mendukung kegiatan pengajian ini.

6. Kesimpulan program penyuluhan pentingnya menabung, yakni kegiatan menabung merupakan hal yang penting untuk dilakukan. Sepantasnya menabung sudah dikenalkan sejak dini, karena menabung mempunyai manfaat di masa depan. Oleh karena itu program ini dilakukan agar anak- anak teringati akan pentingnya menabung. Dalam kegiatan yang berbentuk sosialisasi ini kami melakukannya di sekolah MI Al

\section{DAFTAR PUSTAKA}

Prasetya, E. (2020). 10 Characteristics of SMK Teachers in the Industrial Era 4.0 (Case Study at SMK Bina Profesi Bogor). Edumaspul: Jurnal Pendidikan, 4(1), 50-55. https://doi.org/10.33487/edumaspul.v $\underline{4 \mathrm{i} 1.297}$

Laporan KKN UNY kelompok 2170 pdf. (http://eprints.uny.ac.id/28270/1/LA
Arsaniyah di RW 04 Desa setempat. Dampak yang terlihat, anak- anak begitu antusias dalam memperhatikan program ini. Anak- anak juga sangat senang mendapatkan celengan tabungan yang kami sediakan.

Saran untuk desa : perangkat desa perlu mengadakan penyuluhan atau sosialisasi yang menyadarkan anak- anak akan pentingnya menabung

7. Program gerakan sholat berjama'ah, dalam pelaksanaan program ini ditujukan agar kami yang melakukannya dapat memotivasi remaja yang ada di sekitar mesjid, atau dalam kata lain berdakwah melalui perbuatan.

Saran untuk desa : desa seharusnya mengaktifkan atau membentuk ikatan remaja mesjid di wilayah desa setempat.

8. Kesimpulan dengan adanya program pembuatan dan penyebaran Buletin dakwah Jum'at, merupakan program kami dalam upaya member keilmuan dan seruan berdakwah melalui tulisan. Dampaknya, masyarakat dapat membaca bulletin dakwah yang biasanya tidak ada di mesjid tersebut.

Saran untuk Desa : semoga Desa dapat memperhatikan unsur unsur dakwah bagi masyarakat.

PORAN\%20KKN\%20UNY\%20KE

LOMPOK\%202170.pdf, diakses 12 september 2018)

Buku Panduan KKN UIKA

(https://ladangsolusi.blogspot.com/2012/10

/laporan-individu-kkn-oleh-abdulkarim.html, diakses 12 september 2018) 